\title{
Quality of Brazil nuts stored in forced aeration silos ${ }^{1}$
}

\author{
David Aquino da Costa ${ }^{2}$, Virgínia de Souza Álvares ${ }^{3 *}$, Roberta Martins Nogueira ${ }^{4}$, Jorge Ferreira Kusdra ${ }^{5}$, \\ Vlayrton Tomé Maciel ${ }^{3}$, Daniela Popim Miqueloni ${ }^{6}$
}

10.1590/0034-737X201663030005

\begin{abstract}
The traditional system of collection and storage of Brazil nut compromises seriously the quality of these almonds as it contributes to the high incidence of contaminants, like fungi of the genus Aspergillus, which can produce aflatoxins. In this study, the objective was to evaluate the influence of the storage period in studied conditions, on the physicochemical characteristics and on the microbiological contamination of Brazil nuts. The experimental was designed as completely randomized, considering as treatments the storage period ( 0 - control, 30, 60, 90, 120 and 150 days) with four replicates of $3 \mathrm{~kg}$ of Brazil nuts each. The samples were submitted to physicochemical and microbiological analysis. It was observed that almonds submitted to the storage had their moisture content reduced by $78.2 \%$ at 150 days of storage, however, this reduction was not fast enough to avoid surface contamination by filamentous and potentially aflatoxins producing fungi. The critical period of contamination occurred on the first 30 days of storage when there was an increase of the studied fungi, as well as B1 and total aflatoxin. The studied storage conditions were four times more effective in reducing the product moisture content than the traditional methods, however, pre-drying is necessary to avoid contamination of the product.
\end{abstract}

Key words: Bertholletia excelsa, Storage system, Aflatoxin.

\section{RESUMO}

\section{Qualidade da castanha-do-brasil durante o armazenamento em silo com aeração forçada}

O sistema tradicional de coleta e armazenamento da castanha-do-brasil pode comprometer seriamente a qualidade das amêndoas, pois contribui para a alta incidência de agentes contaminantes, como fungos do gênero Aspergillus, que podem produzir aflatoxinas. Neste trabalho, teve-se por objetivo avaliar a influência do período de armazenamento, nas condições estudadas, sobre as características físico-químicas e a contaminação microbiológica da castanha-do-brasil. O delineamento experimental foi inteiramente casualizado, considerando-se como tratamentos os tempos de armazenamento ( 0 - controle, 30, 60, 90, 120 e 150 dias), com quatro repetições de $3 \mathrm{~kg}$ de castanha-do-brasil cada. As amostras foram submetidas às análises físico-químicas e microbiológicas. Observou-se que o armazenamento reduziu em 78,2\% o teor de umidade das amêndoas ao final de 150 dias, porém essa redução não foi rápida o suficiente para evitar a contaminação por fungos filamentosos totais e potencialmente produtores de aflatoxinas. O período crítico de contaminação ocorreu nos primeiros 30 dias de armazenamento, quando se verificou o aumento dos fungos estudados, bem como de aflatoxinas B1 e total. As condições de armazenamento avaliadas foram quatro vezes mais eficientes na redução de umidade do produto do que o método tradicional de armazenagem, sendo, porém, necessária uma pré-secagem, a fim de se evitar a contaminação do produto.

Palavras-chave: Bertholletia excelsa, sistema de armazenamento, aflatoxina.

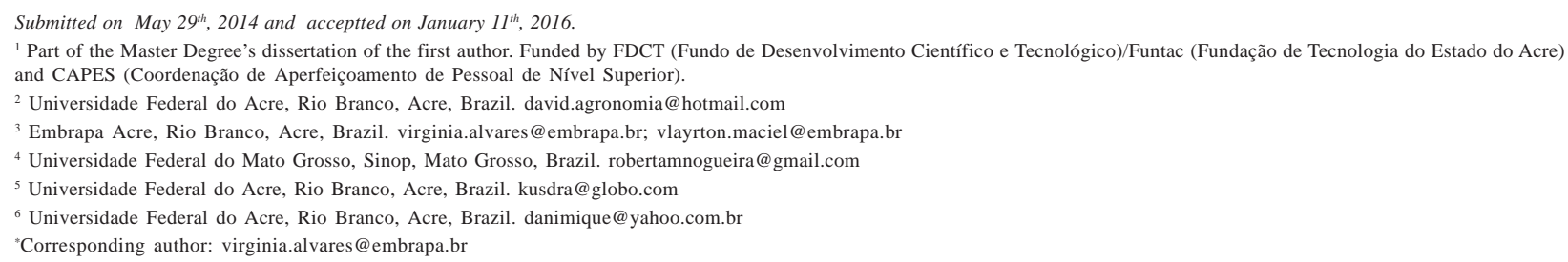




\section{INTRODUCTION}

The Brazil nut (Bertholletia excelsa Humb. \& Bonpl . Lecythidaceae) is considered one of the most important species with economic exploitation of the Amazon rainforest. Almonds are very appreciated for human consumption due to their high nutritional value and health benefits (Massi et al., 2014). The almond contains substantial amounts of antioxidant phenolics, which can effectively control the oxidative stress in the body (John $\&$ Shahidi, 2010). However, some reports state that the presence of aflatoxins, a group of secondary metabolites produced by Aspergillus section Flavi, which are extremely toxic and carcinogenic, are common in the Brazil nut.

The presence of these compounds is due to the traditional system of collection, pre-drying and storage of Brazil nut, which seriously compromises the quality of the almonds, favoring the high incidence of Aspergillus fungi. Despite the regional differences in the production of nuts, extractives generally harvest the pods on the ground, sometimes with long exposure time to high temperatures and humidity of the forest. After the collection, they break the pods still in the forest, exposing the kernels that were previously protected by pods, to other contaminants. After the break, the next step is the pre-drying, performed most often in direct contact with the ground, and some extractives have begun to employ rigid structures with screen background, improving the phytosanitary condition of the product. The most critical points for the infection are after pre-drying, since the moisture of the product after this step also allows the growth of micro-organisms. Álvares et al. (2009) reported that some extractives perform the pre-drying of the product by laying the nuts with shell on a screen floor of a conventional wooden warehouse, at $80 \mathrm{~cm}$ from soil, and keep them with daily turnings under natural aeration. After about 15 days, according to the extractives' experience, the nuts are stored in raffia bags in that warehouse until shipment to the processing plants, with no control over the moisture content of the product, as well as contamination by micro-organisms. These authors also state that the Brazil nut, after the traditional pre-drying at this site, reaches $15 \%$ b.u., reducing by $50 \%$ its initial content, however, this moisture is still not low enough to avoid growth of micro-organisms. Leite (2008), when studying the behavior of the product stored in the predrying conditions mentioned above, found that after 90 days of storage, the nut reaches water activity of 0.74 , exceeding the limit of 0.70 recommended by Arrus et al. (2005a) to prevent production of aflatoxin. The storage conditions of nuts seem to have an important influence on the population of fungi Aspergillus section Flavi (Reis et al., 2014).
These critical conditions for storage are the result of the typical climate of the Amazon region, characterized by high temperatures and rainfall, especially during the harvest season and pre-processing of Brazil nut. All that promotes favorable conditions for the growth of aflatoxins producing fungi, besides the possibility of rewetting the product during storage under natural conditions. Thus, besides the need for efficient drying of the product, taking it to safe water levels, it is necessary that the storage system ensures the maintenance of the reached conditions, preventing the fungi to grow over time.

In this context, the objective of this study was to evaluate the influence of the storage period under the studied conditions, on the physico-chemical characteristics and the microbiological contamination of the Brazil nut.

\section{MATERIAL AND METHODS}

One hundred kilograms of Brazil nut were used, in shell, freshly collected from the Chico Mendes Extractive Reserve (RESEX) in the municipality of Brasiléia, state of Acre, Brazil at $10^{\circ} 49^{\prime} 12^{\prime \prime S}$ and $68^{\circ} 46^{\prime} 18^{\prime \prime} \mathrm{W}$, which were transported to the Food Technology Laboratory at Embrapa in Rio Branco, state of Acre. The product was submitted to six hours of drying in a dryer by natural convection, using wood combustion and the pods (fruit of the Brazil nut tree) as heat sources, and manual control of temperature to $45^{\circ} \mathrm{C}$. During drying, the nuts were arranged in layer of $15 \mathrm{~cm}$ of height and upturned every 30 minutes, reaching average moisture content of $16.47 \%$ b.u., condition close to that obtained under field conditions. After this pre-drying, the nuts were stored for 150 days, from February to July in 2011, in silo type storage (Figure 1), with a capacity of 2,835 $\mathrm{kg}$ of Brazil nut. The silo was built in galvanized steel, with $1.90 \mathrm{~m}$ in diameter and $2 \mathrm{~m}$ in height, with side built in hexagonal mesh screen, with a $30 \mathrm{~mm}$ opening. In the inner part, the side was covered with a plastic sheet, and the air flow was completely directed to the top of the silo, moving throughout the entire mass of the product. The floor where the nuts were laid on, was built of $5 \mathrm{~mm}$ galvanized steel of $5 \mathrm{~mm}$ screen installed above the plenum chamber with $1.90 \mathrm{~m}$ in diameter and $0.40 \mathrm{~m}$ in height. The aeration system consisted of a fan run by 0.5 hp engine and a centrifugal fan with a flow of $332 \mathrm{~m}^{3} \cdot \mathrm{h}^{-1}$ and the static pressure of $20 \mathrm{mmca}$ was installed with the plenum chamber, to allow homogenization of the air flow before passing through the dough of the product. The system was activated every day, when it was not raining for seven consecutive hours (from 9 a.m. to 4 p.m.) during the storage period. The readings of temperature and air environment relative humidity, within the storage silo, were recorded every three hours during the day by a datalogger. 
Before storage, and every 30 days, samples were collected, homogenized and analyzed for moisture in an oven with air circulation at $105^{\circ} \mathrm{C}$ for eight hours; ashes by incineration in a muffle at $540^{\circ} \mathrm{C}(\mathrm{AOAC}, 2012)$; ether extract, by Soxhlet method in an extractor of oil and grease (AOAC, 2012); total crude protein ( $\mathrm{N}$ x 6.25) by the microKjeldahl method with a nitrogen distiller; total crude fiber by digestion in a fiber determiner in $\mathrm{H}_{2} \mathrm{SO}_{4} 1.25 \% \mathrm{p} / \mathrm{v}$ and $\mathrm{NaOH}$ and $1.25 \%$ w/v (AOAC, 2012); total carbohydrates by the difference between the total and the other variables mentioned above; water activity, by direct reading on portable water activity meter; total counts of filamentous fungi and potentially aflatoxin producing fungi by plating by dilution on surface, according to Pitt et al. (1983); aflatoxins B1, B2, G1, G2, and total, by high-performance liquid chromatography, using a fluorescence detector and post-column derivatization by electrochemical cell according to AOAC (2012) and Stroka et al. (2000). For the analysis of aflatoxins, a C18 column was used with flow rate of $1 \mathrm{~mL}$. $\mathrm{min}^{-1}$. The mobile phase used was acetonitrile:methanol:water $(2: 2: 6)$ and the standards used were 0.0015 to $0.0309 \mu \mathrm{g} . \mathrm{mL}^{-1}$ for aflatoxin B1 and G1 and 0.0008 to $0.0153 \mu \mathrm{g} . \mathrm{mL}^{-1}$, for aflatoxin B2 and G2. The experiment was conducted in a completely randomized design with six treatments that consisted of storage times (0 - control, 30, 60, 90, 120 and 150 days of storage) and four replicates with $3 \mathrm{~kg}$ of nuts per replicate.

Data were submitted to verification of discrepant data, normality of errors, and homogeneity of variances, analysis of variance and regression. Regression analysis was used as a reference for defining equations able to explain the behavior of the evaluated variables over time from 0 to 150 days, with intervals of 30 days but the presented data were the observed ones. Pearson correlation was performed to identify the influence of the relationship between the variables in the explanation of the results.

\section{RESULTS AND DISCUSSION}

Storage time of the nuts in the silo-warehouse with aeration influenced the moisture content of almonds reducing it from 16.47 to $3.59 \%$, with a decline of $78.20 \%$ in 150 days (Figure 2). After 90 days of storage, there has already been significant reduction in moisture content of $75.77 \%$ compared with the initial. Álvares et al. (2009), evaluating almonds stored in communities of extractives in Acre, through community paiol warehouse type, found a reduction of only $18.45 \%$ of the moisture content after 90 days of storage (moisture of almonds of $14.96 \%$ before storage to $12.20 \%$ after storage for 90 days) at temperatures ranging from 24.72 to $30.15^{\circ} \mathrm{C}$ and relative humidity from 65.77 to $100 \%$. As the environmental conditions of the work by Álvares et al. (2009) were similar to those of the present work, where temperatures ranged from 26.87 to $29.60{ }^{\circ} \mathrm{C}$ and whose degrees of relative humidity ranged from 62.90 to $84.50 \%$, it can be stated that this great difference in moisture reduction of the product in the same storage time is due to the aeration system in the current storage, which is four times more effective in reducing the moisture content of the almond compared to the traditional community storage room (paiol type) used in the region. As recommended by the Codex Alimentarius (2006), the moisture of the nuts after harvest should be reduced to a safety limit, which according to the Safe Food Program (PAS, 2004), should be less than $13 \%$, a situation obtained after 30 days of storage.

The longest reduction period of moisture content of the nuts (from 0 to 60 days of storage) coincides with the increase of $6.07 \%$ of the room temperature, although there was also an increase of $24.82 \%$ of air relative humidity (Figure 2). However, considering that the aeration occurred during periods of the lowest humidity during the day and that this increase of $24.82 \%$ is average, the direct contact of the stored mass with more humid air was minimal,
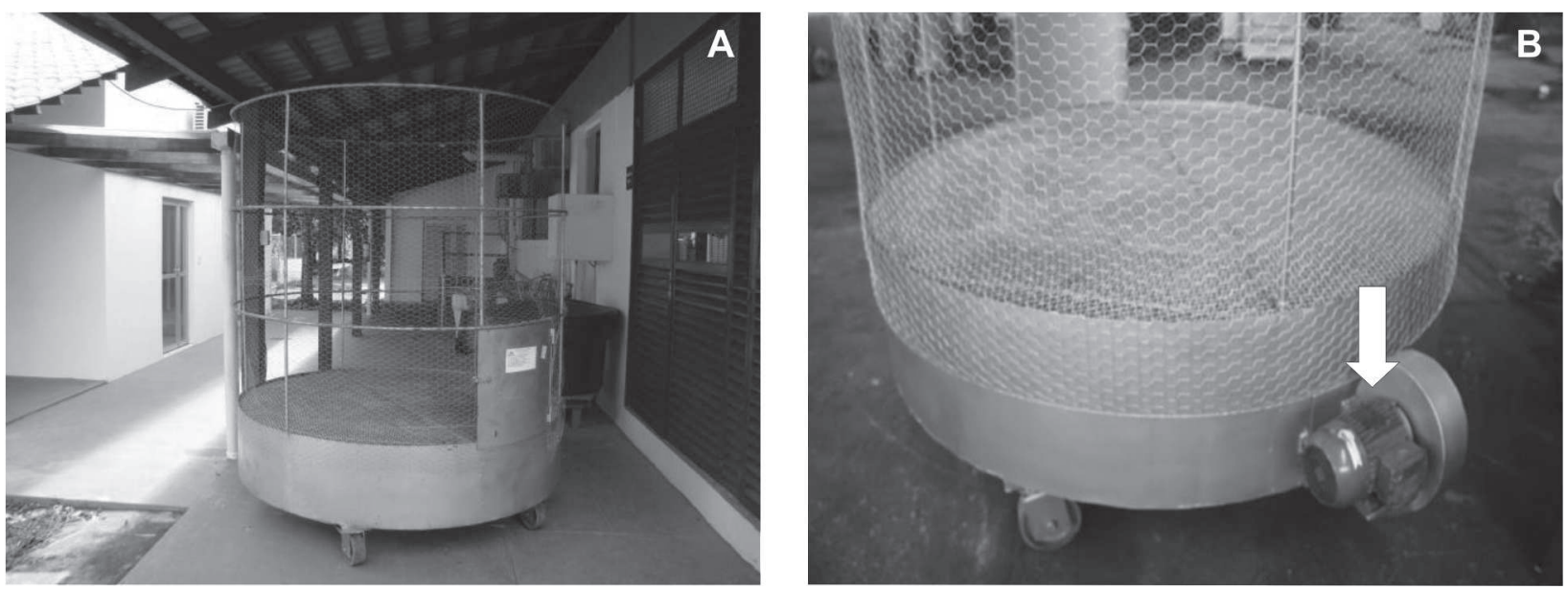

Figure 1: Warehouse-silo with forced air used in the experiment during storage of Brazil nut (A) and fan-driven engine detail (B). 
justifyied by the reduction of moisture content of the nuts even with the increase in relative humidity of the room air.

Regarding the temperatures of the period in study, which ranged from 26.87 to $29.60^{\circ} \mathrm{C}$, they are, according to Molyneux et al. (2007), near to the ideal $26^{\circ} \mathrm{C}$ for growth of Aspergillus flavus and maximum production of aflatoxin by this species.

Since a significant and inverse correlation between moisture content of the almonds and the presence of potentially aflatoxigenic and total filamentous fungi occurred (Table 1), the reduction in the content of moisture was not enough to prevent this contamination, therefore an increase in the count of these fungi, especially in the initial period of storage (Figure 3) was found. According to Garcia et al. (2012), fungal growth depends on the interaction between the temperature and the humidity, which are the most important variables for their growth. Pacheco et al. (2010) also observed a relationship between temperature and relative humidity of the environment in the region, so, the storage should be of short duration.

After the increase period, verified until the first 30 days of period of storage (Figure 3), fungal contamination remained relatively stable with a reduction in moisture content of the environment and almond during storage.

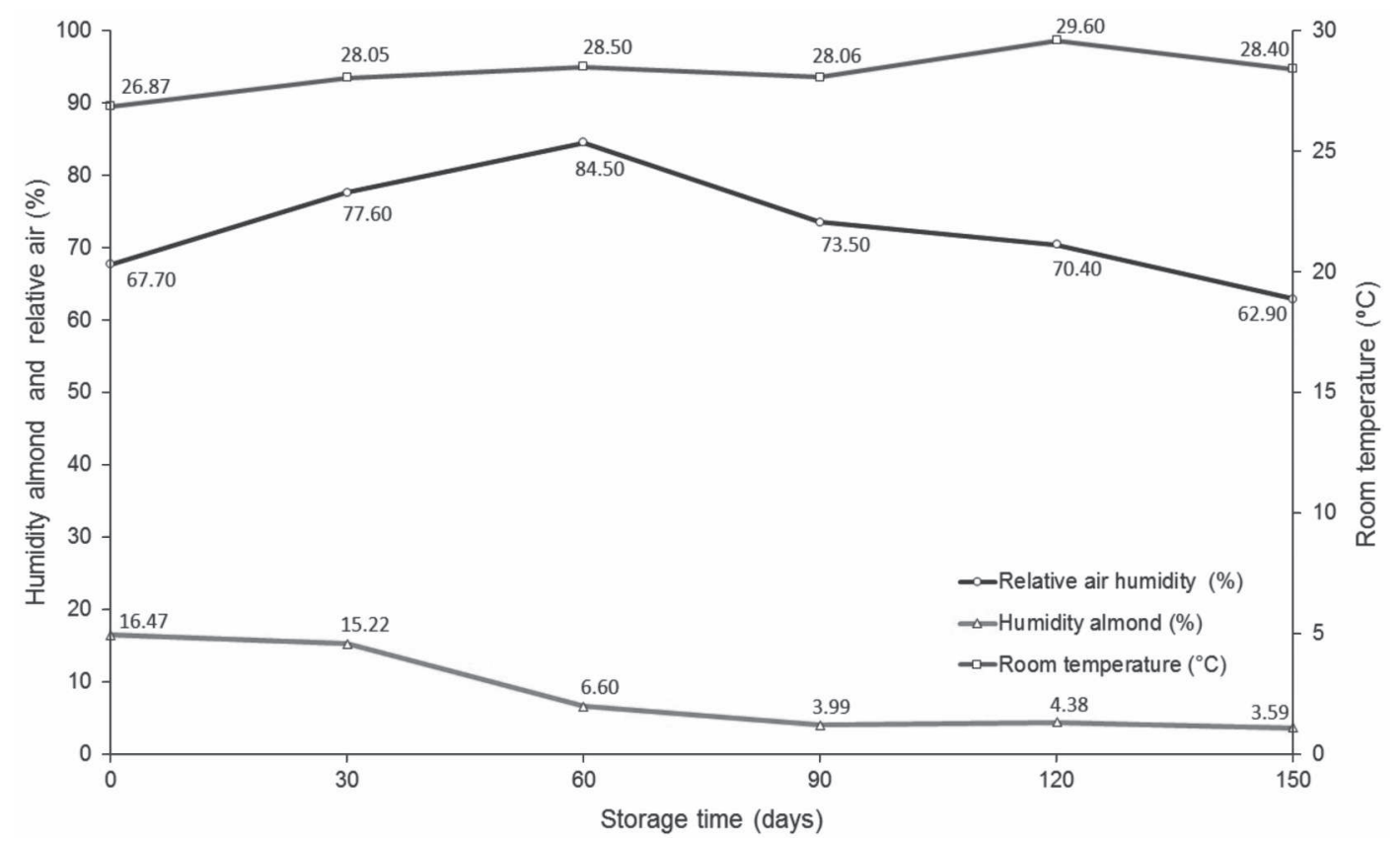

Figure 2: Room temperature and relative humidity of the air and the Brazil nut almonds obtained during storage for up to 150 days in dryer-warehouse after drying by natural convection

Table 1: Correlations between the variables evaluated in Brazil nuts stored in silo in Rio Branco, state of Acre, 2011

\begin{tabular}{|c|c|c|c|c|c|c|c|c|c|c|c|c|c|}
\hline Variables & WA & $\mathbf{A F}$ & TF & AB1 & AB2 & AG1 & AG2 & AT & $\mathbf{A}$ & $\mathbf{P}$ & $\mathbf{E}$ & $\mathbf{F}$ & CB \\
\hline $\mathrm{H}$ & $0.88 * *$ & $-0.62 * *$ & $-0.65^{* *}$ & $-0.73 * *$ & $-0.28^{\mathrm{ns}}$ & $-0.47 *$ & $-0.79 * *$ & $-0.78 * *$ & $-0.91 * *$ & $0.13^{\mathrm{ns}}$ & $0.37^{\mathrm{ns}}$ & $-0.14^{\mathrm{ns}}$ & $-0.44 *$ \\
\hline WA & & $-0.49 *$ & $-0.51 *$ & $-0.52 * *$ & $-0.20^{\mathrm{ns}}$ & $-0.47 *$ & $-0.64 * *$ & $-0.59 * *$ & $-0.87 * *$ & $0.14^{\mathrm{ns}}$ & $0.30^{\text {ns }}$ & $-0.26^{\mathrm{ns}}$ & $-0.34^{\mathrm{ns}}$ \\
\hline $\mathrm{AF}$ & & & $0.94 * *$ & $0.93 * *$ & $0.28^{\mathrm{ns}}$ & $0.27^{\mathrm{ns}}$ & $0.72 * *$ & $0.93 * *$ & $0.33^{\mathrm{ns}}$ & $-0.02^{\mathrm{ns}}$ & $-0.24^{\mathrm{ns}}$ & $0.01^{\mathrm{ns}}$ & $0.40 *$ \\
\hline $\mathrm{TF}$ & & & & $0.95 * *$ & $0.26^{\mathrm{ns}}$ & $0.25^{\mathrm{ns}}$ & $0.74 * *$ & $0.93 * *$ & $0.34 *$ & $-0.00^{\mathrm{ns}}$ & $-0.22^{\mathrm{ns}}$ & $-0.01^{\mathrm{ns}}$ & $0.45^{*}$ \\
\hline $\mathrm{AB} 1$ & & & & & $0.30 * *$ & $0.25 * *$ & $0.82 * *$ & $0.98 * *$ & $0.46^{*}$ & $-0.06^{\mathrm{ns}}$ & $-0.31^{\mathrm{ns}}$ & $0.02^{\mathrm{ns}}$ & $0.45^{*}$ \\
\hline $\mathrm{AB} 2$ & & & & & & $0.16^{\mathrm{ns}}$ & $0.24^{\mathrm{ns}}$ & $0.27^{\mathrm{ns}}$ & $0.18^{\mathrm{ns}}$ & $-0.13^{\mathrm{ns}}$ & $-0.34^{\mathrm{ns}}$ & $-0.35^{\mathrm{ns}}$ & $0.23^{\mathrm{ns}}$ \\
\hline AG1 & & & & & & & $0.42 *$ & $0.40^{\mathrm{ns}}$ & $0.46^{*}$ & $-0.20^{\mathrm{ns}}$ & $0.02^{\mathrm{ns}}$ & $0.26^{\mathrm{ns}}$ & $0.07^{\mathrm{ns}}$ \\
\hline AG2 & & & & & & & & $0.84 * *$ & $0.65 * *$ & $-0.30^{\mathrm{ns}}$ & $-0.24^{\mathrm{ns}}$ & $0.12^{\mathrm{ns}}$ & $0.40^{\mathrm{ns}}$ \\
\hline AT & & & & & & & & & $0.52 * *$ & $-0.07^{\mathrm{ns}}$ & $-0.28^{\mathrm{ns}}$ & $-0.08^{\mathrm{ns}}$ & $0.42 *$ \\
\hline A & & & & & & & & & & $-0.21^{\mathrm{ns}}$ & $-0.39^{\mathrm{ns}}$ & $-0.10^{\mathrm{ns}}$ & $0.39^{\mathrm{ns}}$ \\
\hline $\mathrm{P}$ & & & & & & & & & & & $0.15^{\mathrm{ns}}$ & $0.06^{\mathrm{ns}}$ & $-0.25^{\mathrm{ns}}$ \\
\hline $\mathrm{E}$ & & & & & & & & & & & & $0.42 *$ & $-0.80 * *$ \\
\hline $\mathrm{F}$ & & & & & & & & & & & & & $-0.56 * *$ \\
\hline
\end{tabular}

$\mathrm{H}=$ humidity; $\mathrm{WA}=$ water activity; $\mathrm{AT}=$ almond temperature; $\mathrm{AF}=$ potentially aflatoxin producing fungi; $\mathrm{TF}=$ total filamentous fungi; $\mathrm{AB} 1=$ aflatoxin $\mathrm{B} 1 ; \mathrm{AB} 2=$ aflatoxin $\mathrm{B} 2 ; \mathrm{AG} 1=$ aflatoxin $\mathrm{G} 1 ; \mathrm{AG} 2=$ aflatoxin $\mathrm{G} 2 ; \mathrm{AT}=$ total aflatoxin $\mathrm{CH}=$ centesimal humidity; $\mathrm{C}=$ ash; $\mathrm{P}=$ total crude protein; $\mathrm{E}=$ ether extract $\mathrm{F}=$ total crude fiber; $\mathrm{CB}=$ total carbohydrate. 
Arrus et al. (2005a), when performing storage studies with nuts in shell also observed that the humidity of $5 \%$ avoided the growth of toxigenic fungi. However, in this study, the moisture content of almonds was obtained only after 60 days of storage, indicating that a more efficient pre-drying before storage or in a system with hot air injection in the warehouse are required in order to maintain the quality of the nuts during storage. This recommendation is justified by the fact that the current system depend on local environmental conditions which may increase contamination by fungi even with the relative humidity up to $70 \%$, considered ideal by Codex Alimentarius (2006). This humidity may be relatively low for the region; however, considering the temperature of the medium between 26 and $30{ }^{\circ} \mathrm{C}$, in terms of absolute air humidity, $70 \%$ is quite high, particularly if the air is not heated or ventilated over the product. According to Johnsson et al. (2008) the higher the relative humidity, the faster will be the growth of Aspergillus and mycotoxin production. In this work, the initial increase in the air relative humidity in the first 30 days of storage was enough to trigger the process of increase of fungal contamination of nuts. However, it is found the importance of reducing the moisture of almonds during storage, because even with the continuity of the rainy season and consequent increase in room relative humidity, contamination has stabilized after 60 days of storage (Figure 3).

The storage stage is considered critical in the management of the Brazil nut during post-collection. Fungi known as storage ones are those that develop in seeds or grains with moisture content above $17 \%$ (value approximately close to the one found until 30 days of storage in the experiment), and basically composed by Aspergillus genus. According to Rodrigues et al. (2005), Aspergillus flavus and Aspergillus parasiticus are undoubtedly the most common species belonging to these genera and important producers of aflatoxins in foods.

These results are similar to those obtained by Giorni et al. (2008), who also found fungi in the bands between 17 and $19 \%$ of moisture content in corn grains during storage until 21 days at $25^{\circ} \mathrm{C}$. Therefore, the reduction in moisture and water activity of the seeds by drying is extremely important to reduce the critical levels of contamination (Arrus et al., 2005b), a situation observed in this study using the warehouse with forced ventilation.

Leite (2008) and Arrus et al. (2005a) also observed an increase in the contamination of total and potentially aflatoxigenic fungi in the Brazil nut on the first 30 days of storage. Thus, considering the conditions in the Amazon region, even the 30-day storage can be worrisome, because of the high temperatures and relative humidity of the environment that the nuts are submitted, which are favorable to fungal contamination.

Even with a small increase in counting of fungi at the beginning of storage, it ranged $15.3 \%$, throughout the period for total filamentous fungi (5.04 to $5.81 \log \mathrm{CFU} \mathrm{g}^{-1}$ ) and $34.7 \%$ to potentially aflatoxin-producing fungi (4.23 to $5.70 \log \mathrm{CFU} \mathrm{g}^{-1}$ ), and these variations were lower than $20.5 \%$ and $54.0 \%$, respectively, found by Leite (2008) in warehouse paiol type. Thus, the ventilation system used in the warehouse was more efficient in preventing the increase of contamination during storage.

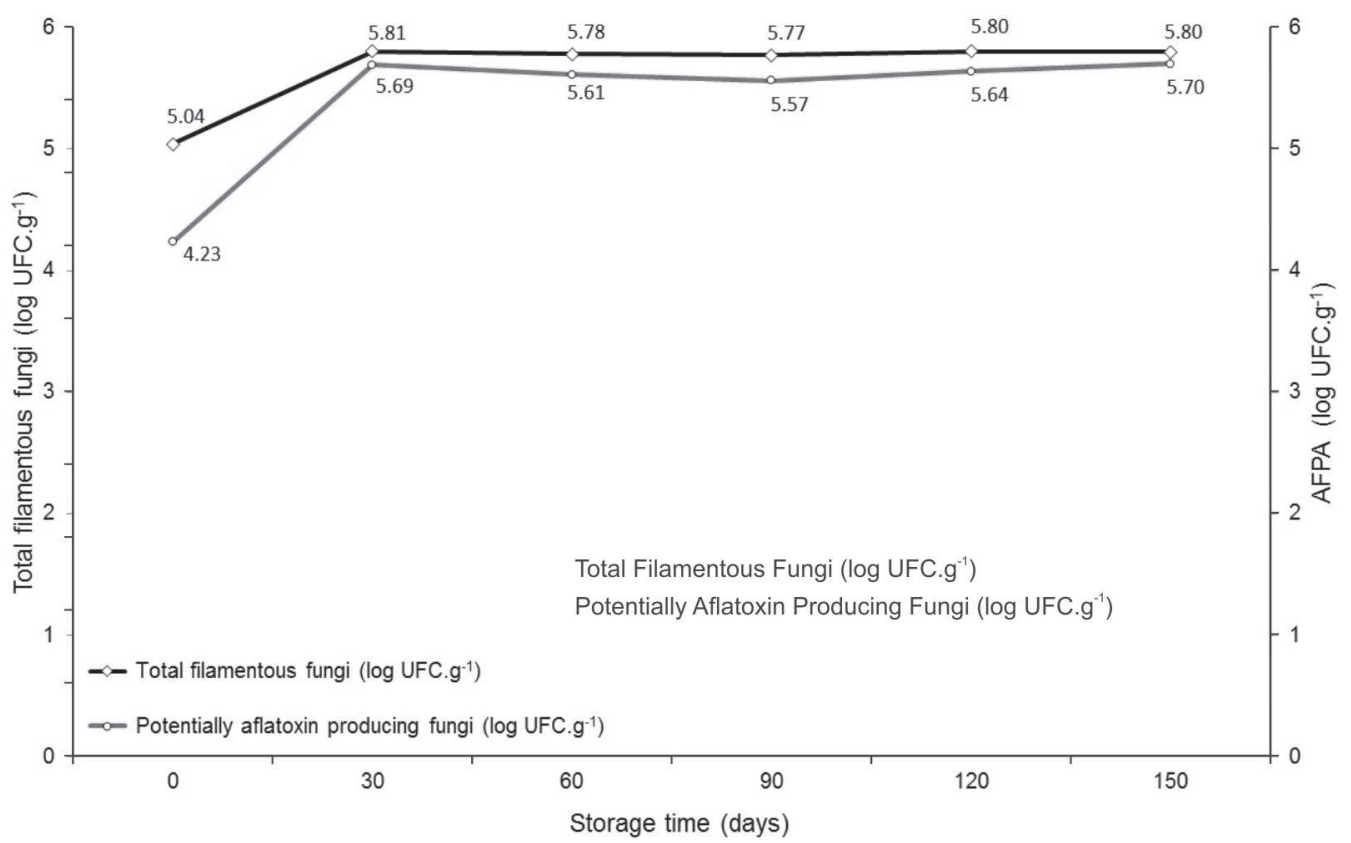

Figure 3: Potentially aflatoxin producing (AFPA) and total filamentous fungi found in almonds of Brazil nuts during their storage for up to 150 days in dryer-warehouse after natural convection drying. 
The water activity of nuts ranged from 0.99 to 0.52 in the studied period, showing a trend of reduction over storage time (Figure 4). The high water activity until 30 days of storage, along with the high humidity of the nuts, may have favored the increase in the count of fungi colonies in this period. This behavior is similar to that observed by Magan \& Aldred (2007), in studies of grain stored in silos, where the authors found that the fungus Aspergillus flavus can develop and produce mycotoxins in the water activity range between 0.73 and 0.85 , fact observed in this work, close to 60 days of storage (Figure 4). According to the Codex Alimentarius (2006), foods with water activity below 0.70 are considered safe in relation to deterioration by micro-organisms, and at this condition, growth of potentially aflatoxin producing fungi and aflatoxin production do not occur.

Storage conditions also provided the appearance of aflatoxin B1 and total in all periods of the study (Figure 5). As for total filamentous and aflatoxin potentially producing fungi, an increase occurred in quantification of total and aflatoxin B1 at the beginning of the storage (Figure 5), even with reduction of moisture content (Figure 2) and water activity (Figure 4 ) of the almonds, since the nuts have already been stored with higher moisture content, where the importance of efficient pre-drying of the product to prevent contamination was found. This increase was also detected by reverse correlation between most of the studied aflatoxins and the moisture content and water activity of almonds (Table 1).
The larger presence of aflatoxin B1 was found on day 60 and for total aflatoxin, at 120 days of storage (Figure 5). Leite (2008), working with chestnuts with an initial water activity of 0.93 , close to the one of this work, which was 0.99 , also observed an increase of contamination by aflatoxin at the beginning of storage. According to Soares et al. (2010), aflatoxin B1 occurs in greater quantities than aflatoxin $\mathrm{B} 2, \mathrm{G} 1$ and $\mathrm{G} 2$.

In periods of larger production of total (120 days) and B1 (60 days) aflatoxins the temperature of the storage room was 28.05 and $29.60{ }^{\circ} \mathrm{C}$ and air relative humidity of 84.50 and $70.4 \%$, respectively. These results are similar to those observed by Arrus et al. (2005a), who found that temperatures from 24.65 to $30{ }^{\circ} \mathrm{C}$ are favorable for the production of aflatoxins in the Brazil nut. According to the same authors, in relation to the air relative humidity, aflatoxins are in the range between 80 and $85 \%$. Thus, it is observed that high temperature and air relative humidity, which are characteristic of the Amazon environment, are perfect to the appearance of fungi, which makes prevention of contamination difficult. However, combined with the climatic conditions, the water activity of the product is a key factor for microbial growth, which explains the reduction of contamination during the studied storage period. It is also important to recognize that the interaction of all these factors provides different results, with regard to fungal growth and mycotoxin production in identical substrates.

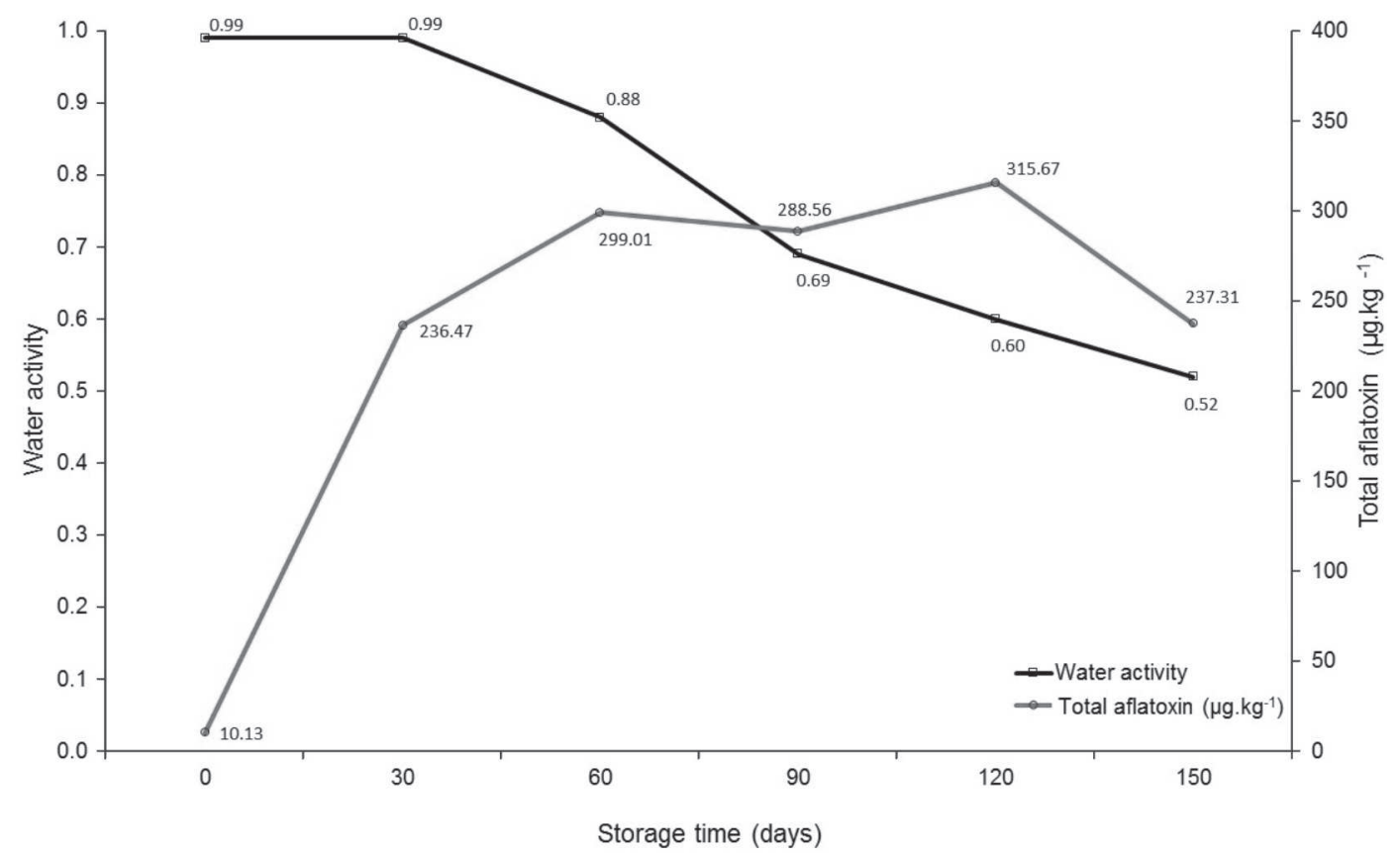

Figure 4: Water activity and total aflatoxin in Brazil nut obtained during its storage for up to 150 days in air forced warehouse after drying by natural convection in an experiment carried out in a completely random design in Rio Branco, Acre, 2011. 
It is observed that even with the reduction in the moisture of almonds to $3.59 \%$ and water activity to 0.52 at the end of storage, the quantification of $273.31 \mu \mathrm{g} . \mathrm{kg}$ ${ }^{1}$ of total aflatoxin detected during this period was high. Aflatoxin is a stable toxin, when it is produced is difficult to be removed. Arrus et al. (2005b), when studying the production of aflatoxins by Aspergillus flavus in dehydrated Brazil nuts, concluded that the drying of the product between 3.5 and $4.0 \%$ of moisture and its maintenance during storage are key points for preventing the synthesis of the toxin. As this silowarehouse under study is to be used by producers even in the communities, it is important that the pre-drying is well performed and the storage period before delivery of the product to the plant, is as short as possible to avoid this contamination.

It was found in this work that the nuts at the beginning of storage were already with $10.13 \mu \mathrm{g} . \mathrm{kg}^{-1}$ of total aflatoxin, which is content close to the maximum limit established by Brazilian legislation to Brazil nuts in shells, $20 \mu \mathrm{g} \cdot \mathrm{kg}^{-1}$. It is observed that these values are even similar to those of the legislation (Brazil, 2011), for nuts intended for direct consumption, with $10 \mu \mathrm{g} . \mathrm{kg}^{-1}$, and for processing, with $15 \mu \mathrm{g} . \mathrm{kg}^{-1}$. Moreover, the values obtained in this work, before storage, were similar to the maximum limits of total aflatoxin set by the European Union for the shelled Brazil nut that are $5 \mu \mathrm{g} . \mathrm{kg}^{-1}$ for aflatoxin B1 and $10 \mu \mathrm{g} . \mathrm{kg}^{-1}$ for total aflatoxin for direct human consumption (European Union Commission, 2010). This reinforces the thesis that the soil may be the main source of fungal contamination of almonds (Arrus et al., 2005b; Baquião et al., 2012; 2013), and these may produce aflatoxins. According to Pas (2004), storage is considered a critical step, because depending on its duration and conduction, fungal growth and production of aflatoxins may occur in greater or lesser extent in humid places, so it is necessary that from the way pods are laid on the forest soil until processing, this should be avoided to favor the necessary conditions to aflatoxigenic strains.

Pacheco et al. (2006), in a study with nuts from two processing plants located in Manaus (AM), in 2005 harvest, found values above those allowed by Brazilian and European legislation for the contamination range, which ranged from $183.42 \mu \mathrm{g} . \mathrm{kg}^{-1}$ to $924.22 \mu \mathrm{g} . \mathrm{kg}^{-1}$ for total aflatoxin. Caldas et al. (2002) also found contamination levels in products consumed in the Federal District, from 1998 to 2001, with maximum levels above those granted by the current laws, and they may mean a risk factor for the population that consumes them regularly.

For Arrus et al. (2005b), an important strategy to prevent aflatoxin in Brazil nut is by interfering in the growth of the fungus after collection through proper control of room temperature and air relative humidity during storage. Nunes et al. (2003) further add that the fungus can be inactivated or removed during processing and not be present in the manufactured product, but mycotoxins can remain as they are not easily eliminated. Therefore, extended storage is only recommended if there is a possibility of locally control relative humidity and room temperature during storage. In the case of this work, for

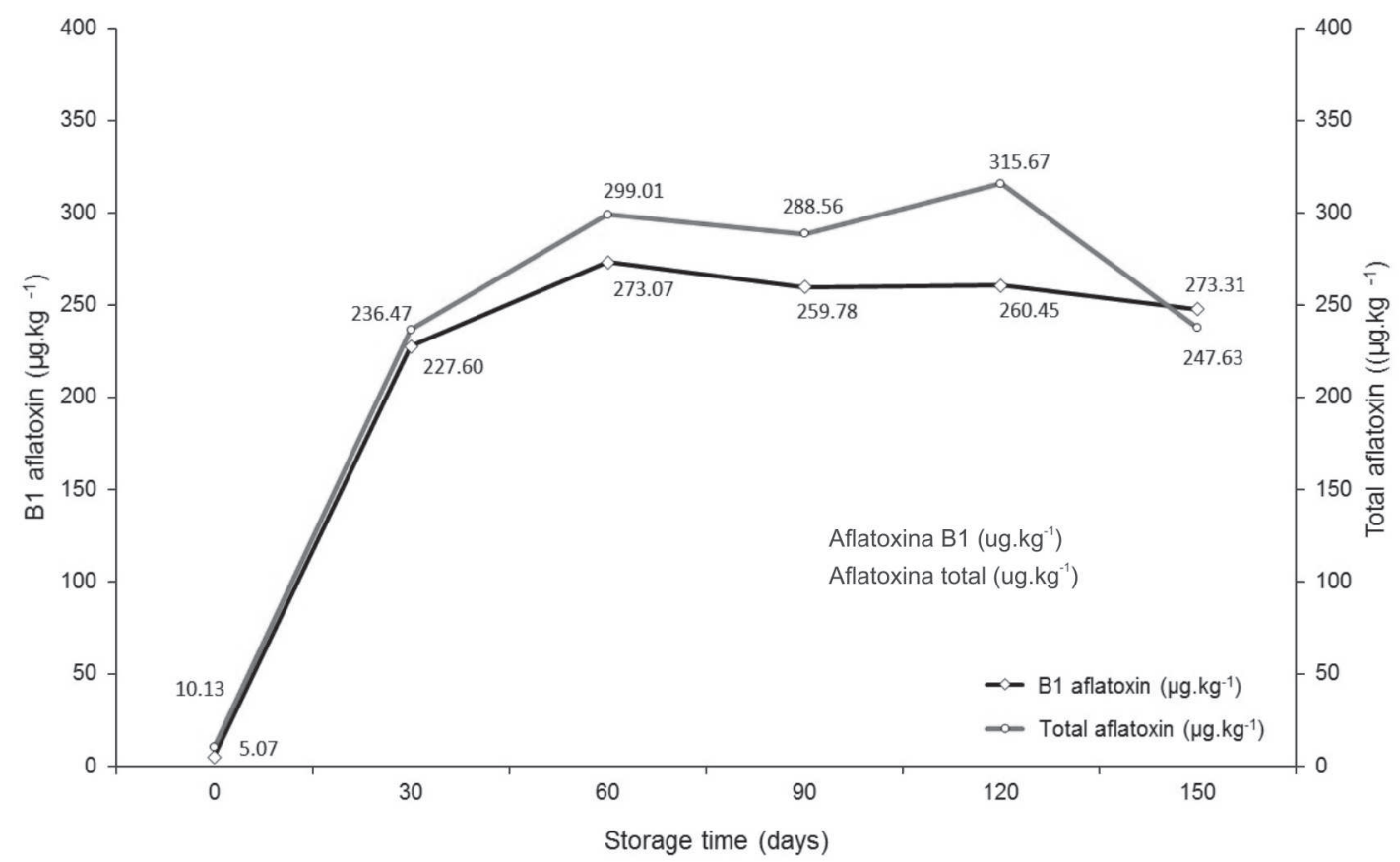

Figure 5: Average values of aflatoxin B1 and total aflatoxin found in almonds of Brazil nuts during their storage for up to 150 days in dryer-warehouse after drying by natural convection. 
storage purposes still in the community, aeration system was used during storage, even with the processes being under environmental conditions, which at the time of collection of chestnuts, was characterized by high temperature and relative air humidity. It is therefore necessary to adjust the system to a smaller influence of environmental conditions on the product, but without increasing the costs for extraction.

It is observed that the contamination by total aflatoxin was represented almost exclusively by aflatoxin B1 (Figure 5), which is in agreement with the observations made by Silva et al. (2008), who concluded that the contamination of seeds by the fungi Aspergillus flavus prevails over Aspergillus parasiticus. This is because Aspergillus flavus produces type B aflatoxin and Aspergillus parasiticus produces $\mathrm{G}$ type aflatoxins, also suggesting that the main responsible for the contamination of nuts in this work were the Aspergillus flavus fungi species. On the other hand, it is also known that not all isolates of Aspergillus flavus obtained from agricultural products are able to synthesize aflatoxins (Freire; Kozakiewicz et al., 2005). However, according to Olsen et al. (2008), the major responsible for aflatoxin production may not be Aspergillus flavus but Aspergillus nomius. So, the occurrence of both species in Brazil nuts should be further studied to define prevention and control strategies of aflatoxins in this product.

According to Garcia et al. (2012), aflatoxin B1 is the most toxic and presents carcinogenic properties, occurring in larger quantities than the other aflatoxins, considered the main aflatoxin in agricultural products. This toxin has been identified in other products besides Brazil nut, as in animal diets (Oliveira et al., 2010) and peanut sweets (Glória et al., 2006), making their export to foreign markets difficult (Mello \& Scussel, 2007), in view of the strict control of the maximum levels of aflatoxins permitted in these products.

Regarding the centesimal composition, the storage period has changed only the ash content (Figure 6) and total carbohydrates (Figure 7) of almonds (Figures 5 and 6 ). The ash content ranged from 3.12 to $3.92 \%$, during storage up to 150 days and the total carbohydrates from 2.65 to $14.58 \%$. Thus, the average values for ash (3.64\%), protein (15.29\%), ether extract $(63.86 \%)$, crude fiber ( $8.03 \%)$ and total carbohydrates $(9.05 \%)$ were not influenced by storage, in which similar results were found in other places such as Xapuri, also in Acre, by Souza and Menezes (2004), in Brazil nuts stored with shell, in Pará, and by Santos et al. (2011), in broken and dehulled nuts.

The average content of total crude protein was $15.29 \%$ during the storage period of up to 150 days. This value is statistically equal to those obtained by Ferreira et al. (2006) (15.60\%), Queiroga Neto et al. (2009) (16.50\%) and Santos et al. (2011) (18.58\%). These values confirm that the nut is a rich protein source, since according to Cardarelli and Oliveira (2000), this situation occurs when the almond presents 15 to $20 \%$ of protein.

For the ether extract content, an average of $63.86 \%$ was found during the storage period of up to 150 days. This value is statistically equal to those obtained in other works, such as Ferreira et al. (2006), Queiroga Neto et al. (2009) and Santos et al. (2011), with averages of 61.00, 66.23 and $65.33 \%$, respectively, confirming the lipid richness of this food. According to Cardarelli and Oliveira (2000) the ether extract of Brazil nut ranges from 60 to $70 \%$,

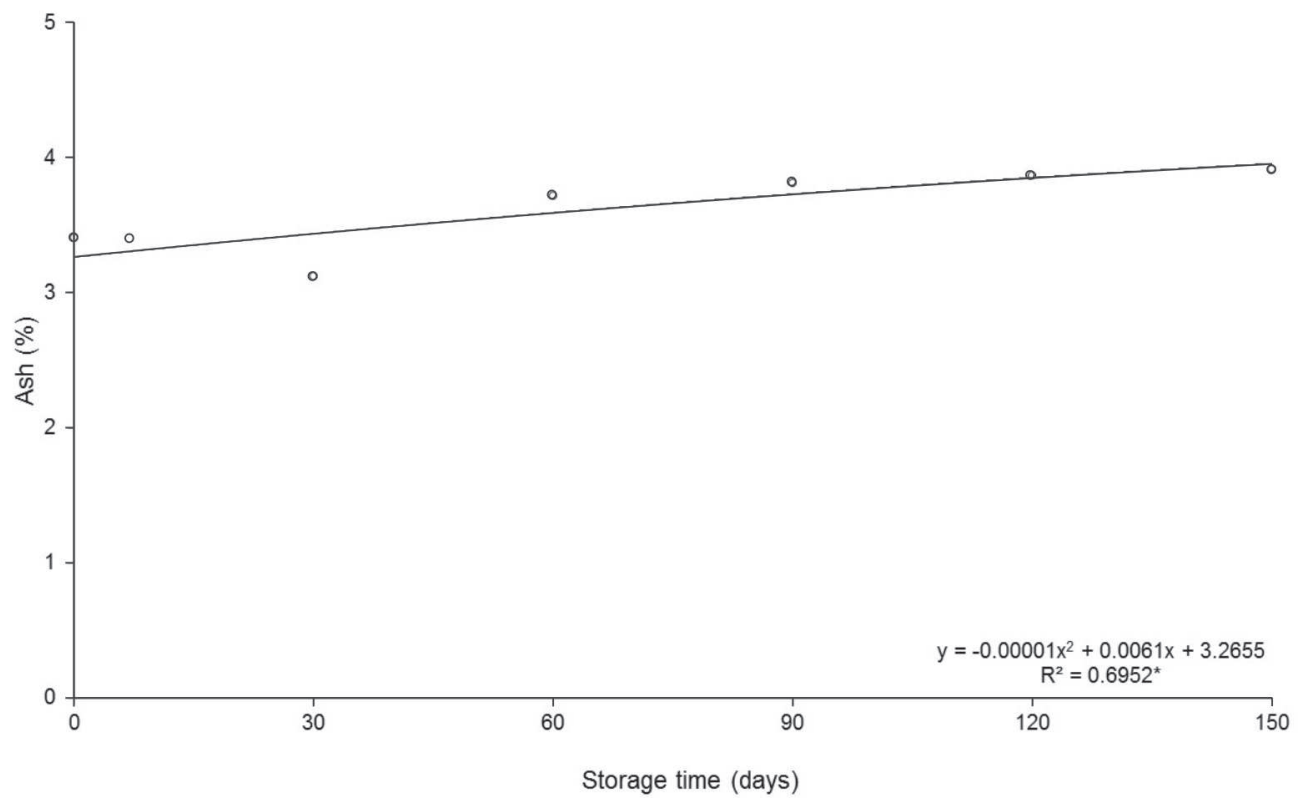

Figure 6: Ash content of the Brazil nut during storage for up to 150 days in air forced warehouse after drying by natural convection, in an experiment conducted in a completely randomized design, in Rio Branco, Acre, 2011. 


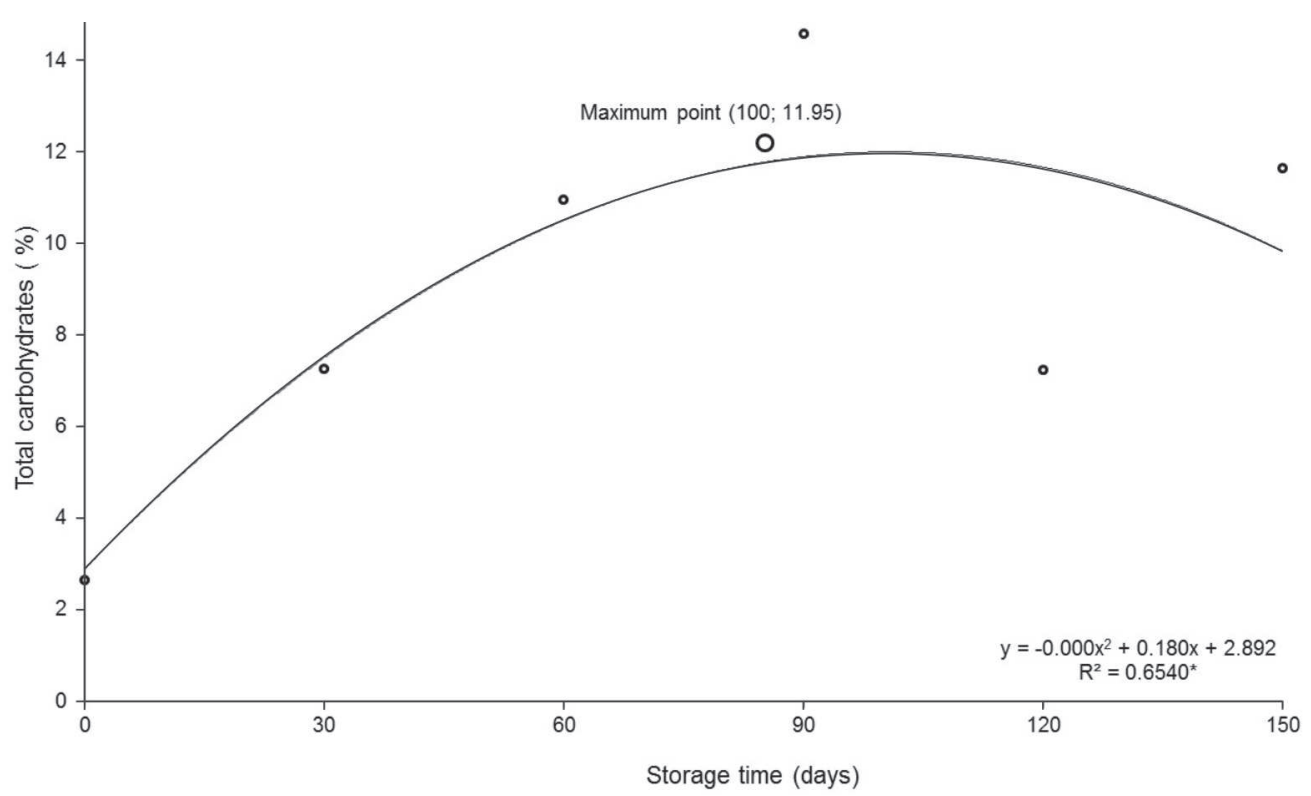

Figure 7: Content of total carbohydrates of Brazil nut during storage for up to 150 days in dryer-warehouse after drying by natural convection, in an experiment conducted in a completely randomized design, in Rio Branco, Acre, 2011.

presenting good biological quality. However, Silva and Marsaioli Junior (2003) found that high lipid content in Brazil nut can make it very susceptible to rancidity. Furthermore, aflatoxin producing fungi use glycerin (oil component) as a heat source. However, this constituent is important from a nutritional point of view, as the largest component of the almond of Brazil nut is the fatty linolenic acid, widely recognized as essential fatty acid, of great importance for human consumption (Rodrigues et al., 2005).

The average content of total crude fiber found during the storage was $8.03 \%$. This value is statistically equal to those obtained by Gloria and Regitano-d'Arce (2000), Souza and Menezes (2004), Ferreira et al. (2006a), Souza and Menezes (2004) with means of 8.02, 8.02, 7.79 and 7.00\%, respectively.

\section{CONCLUSIONS}

Almonds of Brazil nuts stored in forced air circulation system reduces moisture content and kept the physicochemical characteristics at appropriate levels, but the microbiological variables increases, especially at the beginning of storage.

\section{ACKNOWLEDGEMENTS}

The authors of this work thank the Coordination for the Improvement of Higher Education Personnel (CAPES), to National Reserach Council (CNPq), to the Federal University of Acre (UFAC), to Technology Fundation of Acre State (FUNTAC) and to the Agricultural and Livestock Brazilian Research Company (EMBRAPAAcre).

\section{REFERENCES}

Álvares VS, Leite FMN, Madruga ALS, Souza JML \& Costa DAC (2009) Monitoramento da cadeia produtiva da castanha-dobrasil quanto à contaminação por coliformes e fungos em três castanhais do Acre. In: VII Seminário Anual de Cooperação UFAC/UF, Rio Branco. Anais, UFAC. p.211-217.

Arrus AK, Blanka G, Abramsonb D, Clearc R \& Holley RA (2005a) Aflatoxin production by Aspergillus flavus in Brazil nuts. Journal of Stored Products Research, 41:513-527.

Arrus K, Blank G, Clear R, Holley RA \& Abramsonb D (2005b) Microbiological and aflatoxin evaluation of Brazil nut pods and the effects of unit processing operations. Journal of Food Protection, 68:1060-1065.

AOAC - Association of Ofûcial Analytical Chemist (2012) Official Methods of Analysis. 19a ed. AOAC, Gaithersburg. 3000p.

Baquião AC, Zorzete P, Reis TA, Assunção E, Vergueiro S \& Correa B (2012) Mycoflora and mycotoxins in field samples of Brazil nuts. Food Control, 28:224-229.

Baquião AC, Oliveira MMM, Reis TA, Zorzete P, Diniz Atayde D \& Correa B (2013) Polyphasic approach to the identification of Aspergillus section Flavi isolated from Brazil nuts. Food Chemistry, 139:1127-1132.

Brasil (2011) Resolução RDC n ${ }^{\circ}$ 7, de 18 de fevereiro de 2011. Ministério da Saúde, Agência Nacional de Vigilância Sanitária (Anvisa). Dispõe sobre limites máximos tolerados (LTM) para micotoxinas em alimentos. DOU, 18/02/2011. Seção1, p.6667.

Cardarelli HR \& Oliveira AJ (2000) Conservação do leite de castanha-do-brasil. Scientia Agrícola, 57:617-622.

Codex Alimentarius (2006) Code of practice for the prevention and reduction of aflatoxina contamination in tree nuts. CAC/ RCP, 59:01-09.

Caldas W, Silva S \& Oliveira J (2002) Aflatoxinas e ocratoxina A em alimentos e riscos para a saúde humana. Journal of Public Health, 36:319-323. 
European Union Commission (2010) Commission Regulation $\mathrm{n}^{\mathrm{o}}$ 165/10 of Feb 2010 amending Regulation № 1881/06, setting maximum levels for certain contaminants in foodstuffs as regards aflatoxins. Official Journal of the European Communities, 50:0812.

Ferreira ES, Silveira CS, Lucien VG \& Amaral AS (2006) Caracterização físico-química da amêndoa, torta e composição dos ácidos graxos majoritários do óleo bruto da castanha do Brasil (Bertholletia excelsa H. B. K.). Brazilian Journal of Food and Nutrition, 17:203-208

Freire FCO \& Kozakiewicz Z (2005) Filamentous fungi, bacteria and yeasts associated with cashew kernels in Brazil. Revista Ciência Agronômica, 36:249-254.

Garcia D, Ramos AJ, Sanchis V \& Marín S (2012) Effect of Equisetum arvense and Stevia rebaudiana extracts on growth and mycotoxin production by Aspergillus flavus and Fusarium verticillioides in maize seeds as affected by water activity. International Journal of Food Microbiology, 153:21-27.

Giorni P, Battilani P, Pietri A \& Magan N (2008) Effect of aw and $\mathrm{CO}_{2}$ level on Aspergillus flavus growth and aflatoxin production in high moisture maize post-harvest. International Journal of Food Microbiology, 122:109-113.

Glória EM, Romero AC, Carvalho APP, Domingues MAC \& Gonçalves PVM (2006) Aflatoxin contamination profile among packages of peanut candies. Ciência e Tecnologia de Alimentos, 26:660-665.

John JA \& Shahidi F (2010) Phenolic compounds and antioxidant activity of Brazil nut (Bertholletia excelsa). Journal of Functional Foods, 2:196-209.

Johnsson P, Lindblad M, Thim AM, Jonsson N, Vargas EA, Medeiros NL, Brabet C, Araújo MQ \& Olsen M (2008) Growth of aflatoxigenic moulds and aflatoxina formation in Brazil nuts. World Mycotoxin Journal, 2:127-137.

Leite FMN (2008) Fungos aflatoxigênicos na castanha-do-brasil sob as condições da floresta e de armazenagem comunitária no Acre. Dissertação de Mestrado. Universidade Federal do Acre, Rio Branco. 97p.

Magan N \& Aldred D (2007) Post-harvest control strategies: Minimizing mycotoxins in the food chain. International Journal of Food Microbiology, 119:131-139.

Massi FP, Vieira MLC, Sartori D, Penha RES, Munhoz CF, Ferreira JM, Iamanaka BT, Taniwaki MH, Frisvad JC \& Fungaro MHP (2014) Brazil nuts are subject to infection with B and G aflatoxinproducing fungus, Aspergillus pseudonomius. International Journal of Food Microbiology, 186:14-21.

Mello FR \& Scussel VM (2007) Characteristics of in-shell Brazil nuts and their relationship to aflatoxina contamination: criteria for sorting. Journal of Agricultural and Food Chemistry, 55:9305-9310.

Molyneux RJ, Mahoney N, Kim JH \& Campbell BC (2007) Mycotoxins in edible tree nuts. International Journal of Food Microbiology, 2:72-78.

Nunes IL, Magagnin G, Bertolin TE \& Furlong EB (2003) Arroz comercializado na região Sul do Brasil: aspectos micotoxicológicos e microscópicos. Ciência e Tecnologia de Alimentos, 23:190-194.
Oliveira CAF, Sebastião LS, Fagundes H, Rosim RE \& Fernandes AM (2010) Determination of aflatoxin B1 in animal feed and aflatoxin M1 in raw milk in farms located in the São Paulo. Ciência e Tecnologia de Alimentos, 30:221-225.

Olsen M, Johnsson P, Moller T, Paladino R \& Lindblad M (2008) Aspergillus nomius, an important producer in Brazil nuts? World Mycotoxin Journal, 1:123-126.

Pacheco AM, Robert F \& Scussel V (2006) Detecção de aflatoxinas em castanha-do-brasil (Bertholletia excelsa H. B. K) na safra de 2005. Revista Analítica, 22:64-65.

Pacheco AM, Lucas A, Parente R \& Pacheco N (2010) Association between aflatoxin and aflatoxigenic fungi in Brazil nut (Bertholletia excelsa H.B.K.). Ciência e Tecnologia de Alimentos, 30:330-334.

PAS - Programa de Alimentos Seguros (2004) Manual de segurança e qualidade para a cultura da castanha-do-brasil. Brasília, Embrapa. 62p.

Pitt JI, Hocking, Ailsa D \& Glenn Iannre (1983) An improved medium for the detection of Aspergillus fravus and A. parasiticus. Journal of Applied Bacteriology, 54:109-114.

Queiroga Neto V, Bakke OA, Ramos CMP, Bora PS, Letelier JC \& Conceição MM (2009) Brazil nut (Bertholletia excelsa H. B. K) seed kernel oil: characterization and thermal stability. Revista de Biologia e Farmácia, 3:33-42.

Reis TA, Baquião AC, Atayde DD, Grabarz F \& Corrêa B (2014) Characterization of Aspergillus section Flavi isolated from organic Brazil nuts using a polyphasic approach. Food Microbiology, 42:34-39.

Rodrigues JE, Araújo ME, Azevedo FFM \& Machado NT (2005) Phase equilibrium measurements of Brazil nut (Bertholletia excelsa) oil in supercritical carbon dioxide. Journal of Supercritical Fluids, 34:223-229.

Santos OV, Corrêa NCF \& Lannes SCS (2011) Caracterização física, físico-química, microbiológica e micotoxicologica da castanha-do-brasil (Bertholletia excelsa H. B. K.). Revista Iluminart, 12:48-59.

Silva FA \& Marsaioli Jr. A (2003) Aspecto econômico de um processo de secagem de amêndoas de castanha do Brasil (Bertholletia excelsa) assistida a microondas. Revista Ciências Exatas e Naturais, 5:157-167.

Silva JO, Cândido LMB, Novello D \& Machado C (2008) Ocorrência de aflatoxinas em arroz consumido por militares do exército brasileiro por cromatografia em camada delgada e cromatografia líquida de alta eficiência. Ciência e Agrotecnologia, 32:1238-1244.

Soares C, Rodrigues P, Freitas-Silva O, Abrunhosa L \& Venâncio A (2010) HPLC method for simultaneous detection of aflatoxins and cyclopiazonic acid. World Mycotoxin Journal, 3:225-231.

Souza ML \& Menezes HC (2004) Processamentos de amêndoa e torta de castanha-do-brasil e farinha de mandioca: parâmetros de qualidade. Ciência e Tecnologia de Alimentos, 24:120-128.

Stroka J, Anklam E, Jorissen U \& Gilbert J (2000) Immunoaffinity column cleanup with liquid chromatography using post-column bromination for determination of aflatoxins in peanut butter, pistachio paste, fig paste and paprika powder: collaborative study. Journal of AOAC, 83:320-340. 